УДК 339:1

\title{
ФОРМУВАННЯ ІННОВАЦІЙНОЇ ЕКОСИСТЕМИ ВІТЧИЗНЯНОї СФЕРИ РІТЕЙЛУ
}

\section{INNOVATIVE ECOSYSTEM FORMATION OF DOMESTIC RETAIL SPHERE}

\author{
Оліх Леся Анатоліївна \\ кандидат економічних наук, доцент, \\ Київський національний університет імені Тараса Шевченка \\ ORCID: https://orcid.org/0000-0002-4365-8107 \\ Іваницька Лілія Олександрівна \\ студентка, \\ Київський національний університет імені Тараса Шевченка \\ ORCID: https://orcid.org/0000-0003-4423-0783
}

\author{
Olikh Lesya, Ivanytska Liliya \\ Kyiv National Taras Shevchenko University
}

\begin{abstract}
Стаття присвячена особливостям інноваційного розвитку та впровадженню цифрових технологій у ссрері рітейлу. Авторами визначені поняття інноваційної екосистеми та основні її учасники, розкрито особливості її фрормування у вітчизняній сорері рітейлу на прикладі ТОВ «Інтертоп Україна». Охарактеризовано основні напрями змін у сорері рітейлу та необхідність їх активізації за умов пандемії, спричиненої COVID-19. У статті представлено, які технологічні зміни відбулись у ТОВ «Інтертоп Україна» за останній рік та які нові продукти планується впровадити для підвищення якості обслуговування клієнтів і збереження конкурентних позицій на ринку. Охарактеризовано основні смарт-модулі системи «Інтертоп+». Методом багатокритеріального аналізу було визначено, з якою компанією доцільніше співпрацювати ТОВ «Інтертоп Україна» для замовлення технологічної продукції.
\end{abstract}

Ключові слова: інноваційна екосистема, учасники інноваційної екосистеми, сорера рітейлу, багатокритеріальний аналіз, цифррові технології.

Статья посвящена особенностям инновационного развития и внедрения цифровых технологий в ссрере ритейла. Авторами определены понятие инновационной экосистемы и основные ее участники, раскрыты особенности ее формирования в отечественной сфере ритейла на примере ООО "Интертоп Украина". Охарактеризовано основные направления изменений в сфере ритейла и необходимость их активизации в условиях пандемии, причиной которой является COVID-19. В статье представлено, какие технологические изменения произошли в ООО "Интертоп Украина" за последний год и какие новые продукты планируется внедрить для повышения качества обслуживания клиентов и сохранения конкурентных позиций на рынке. Дана характеристика основным смарт-модулям системы “Интертоп+". Методом многокритериального анализа было определено, с какой компанией целесообразно сотрудничать ООО "Интертоп Украина" для заказа технологической продукции.

Ключевые слова: инновационная экосистема, участники инновационной экосистемы, сфера ритейла, многокритериальный анализ, циорровые технологии.

The article is devoted to the innovative development peculiarities and digital technologies implementation in the retail sphere. The authors determine such category as "innovative ecosystem" and its typical actors. They are research institutions, incubators and accelerators, angel investors, venture capitalists, private equity firms, government, friends and family, civil society organizations, development agencies, professionals, start-ups and enterprises, market facilitators and intermediaries, private companies. Innovative ecosystem formation of domestic retail sphere is presented at the example of LTD "Intertop Ukraine". The changes main directions in the retail sphere and the necessity of their activization because of COVID-19 are characterized. They are business model evolution, company philosophy and goal, rethinking the cost of doing business, the client's choice is considered under a "microscope". The article deals with the technological changes which have taken place in LTD "Intertop Ukraine" last year. There are presented new products in the article. They are planned to implement in order to improve the quality of cus- 
tomer service and to maintain a competitive position in the market. The main "Intertop+" system smart-modules are characterized. They are "Intertop+" fitting room, "Intertop+" personal digital assistant, "Intertop+" information post, "Intertop+" shelf, "Intertop+" POS, "Intertop+" media station, "Intertop+" anti-theft system. Using the method of multicriterial analysis there was distinguished which company it is more expedient to cooperate LTD "Intertop Ukraine" with to custom technological products. We evaluate four alternative companies (Hewlett Packard, Intel, RDN, Arm) according to the criteria: number of implemented projects, the number of implemented chips is in the field of retail, the breadth of the portfolio of services and functionality of the manufacturer for the production of chips, cost of services, number of victories in professional projects and place in the world ranking of companies for the production and implementation of chips.

Keywords: innovative ecosystem, innovative ecosystem typical actors, retail sphere, multicriterial analysis, digital technologies.

Постановка проблеми. Відповідно до теорії циклічного розвитку людське суспільство та відносини, що його формують, на кожному новому етапі повторюють набір дій у якісно новому виконанні. Природна система і система, сорормована людиною, розвиваються у тісній взаємодії, не зважаючи на суперечки i протистояння. Дане поєднання виявляється й у розвитку різних наукових напрямів. Зокрема воно знаходить своє відображення у міждисциплінарному використанні наукової термінології. Не $є$ новинкою використання категоріального апарату природничих наук у дослідженнях представників суспільних наук.

Термін «екосистема» має пряме відношення до біологічних наук і трактується як середовище проживання живих організмів у сприятливих для них умовах, що опосередковується наявністю відповідних взаємозв'язків між ними. Вдалим було запозичення даного терміну і використання його в сучасних теоріях інноваційного розвитку.

Аналіз останніх досліджень і публікацій. Поняття інноваційної екосистеми не $є$ новим. Але становить інтерес для дослідження в окремих галузях та видах діяльності вітчизняної економічної системи. Теоретичні засади становлення і розвитку інноваційних екосистем розкриті у працях Adner R., Bramwell A., Chessell M., Munro T., Rothschild M., Russell M. та інших. Практичні засади формування і розвитку інноваційних екосистем у вітчизняній сорері рітейлу представлені у працях Федулової Л.І., Петренко Л.А., Ляшенко О.М. та інших.

Виділення невирішених раніше частин проблеми. Потребують подальшого дослідження питання розвитку інноваційної екосистеми сорери рітейлу за умов прискореної цифрровізації діяльності підприємств даного спрямування, зумовленої пандемією, спричиненою COVID-19.

Формулювання цілей статті. Метою статті виступає розкриття особливостей розвитку інноваційної екосистеми вітчизняної ссрери рітейлу на прикладі ТОВ «Інтертоп Україна».

Виклад основного матеріалу. Інноваційна екосистема являє собою відповідне середовище та сукупність у ньому учасників, які, через власну специфічну діяльність, у спільній взаємодії забезпечують неперервне здійснення окремих стадій інноваційного процесу та реалізацію інноваційного циклу загалом. Учасниками інноваційної екосистеми за підходом International Development Innovation Alliance (IDIA) $€$ [5]: науково-дослідні організації, інкубатори і акселератори, бізнес-ангели, венчурні капіталісти, фрірми приватного капіталу, уряд, друзі і родина, громадські організації, агентства з розвитку, профресіонали, стартапи і підприємства, ринкові посередники, приватні компанії.

Одним із напрямів економічної діяльності, яка завжди гнучко реагує на зміни умов функціонування, $є$ роздрібна торгівля. Перебуваючи у безпосередньому контакті з кінцевим споживачем та прагнучи зберігати конкурентну позицію за умов динамічного середовища, представники рітейлу є не тільки відкритими до інновацій, а самі виступають їх джерелом. Поштовхом до активних змін у даній сорері стала пандемія, спричинена COVID-19, яка прискорила технологічні зміни та циорову трансформацію суб'єктів господарювання [6]:

І. Еволюція бізнес-моделі:

- зниження частки продажів через мережу фрізичних магазинів;

- відкриття або розширення діяльності інтернет-магазинів;

- пошук платфрормних компаній для допомоги у реалізації можливостей.

II. Філософрія та мета компанії трансорормуються: безпека громадян і працівників $€$ першочерговою - вище прибутків;

III. Переосмислення вартості ведення бізнесу:

- звичні фрорми зниження витрат більше не $€$ достатніми для підтримки маржі та відновлення бізнесу; 
- впровадження агресивних стратегій стримування витрат;

- прогнозування інвестиційного пожвавлення у сорері підвищення вартості існуючих активів.

IV. Вибір клієнта розглядається під «мікроскопом»:

- зміна пріоритетів споживачів - менше дбають про асортимент товарів і більше про їхню наявність і доступність;

- першочергова увага - товарам першої необхідності;

- зміна ієрархії потреб споживачів відповідно до умов середовища.

Актуальними дані напрями єй для ТОВ «Інтертоп Україна» - одного з потужних учасників вітчизняної сорери рітейлу. У 2020 р. дана компанія впровадила нову ERP-систему, що знайшло відображення у введені в дію таких технологій [7]:

- Спеціалізоване рішення для галузі рітейл SAP CAR дає змогу збирати дані 3 POSтерміналів, аналізувати продажі та $€$ основою для подальшої прогнозної аналітики.

- Розроблений фуункціонал для обліку ПдВ, який застосовується для оптових і роздрібних продажів, а також інтернет-продажів на базі SAP S/4HANA. Цього модуля немає у класичній конорігурації, але він потрібен усім рітейлерам.

- Інтеграція IT-рішень INTERTOP для складу, управління магазинами, системами лояльності тощо з S/4HANA. Для цього командою консультантів AGELESS були розроблені універсальні об'єкти інтеграції, які через інтеграційну шину зв'язали усі необхідні системи в єдиний інформаційний простір.

- Весь цикл інтернет-продажів реалізований у SAP S/4HANA.

Використовуючи SAP S/4HANA як цифррового ядра для власних бізнес-процесів, INTERTOP ставить перед собою завдання трансорормації логістичної системи, а також стандартизації та спрощення господарських операцій всіх підрозділів і підприємств. Система дозволяє компанії забезпечити контроль ефрективності в частині планування та поліпшення відповідності результатів запланованим показникам на якісно новому рівні. А єдина IT-платорорма дозволить, за необхідності, реалізувати гнучке масштабування під зростаючі потреби бізнесу.

Впроваджені технології дозволять пришвидшити запровадження та модернізацію у мережі системи так званих смарт-модулів «Інтертоп +» [12]:

1. «ннтертоп +» примірочна:

- одяг 3 міткою RFID, який приносять у примірочну, зчитується антеною, і предмети з'являються на екрані;
- покупець зможе ознайомитись 3 кожним продуктом, йому буде надана детальна інорормація про товар та перелік магазинів, де він наявний;

- фрункція перехресних продажів - система буде постійно відстежувати, які елементи вибрані та пропонувати відповідні варіанти одягу, аксесуарів або взуття, щоб доповнити образ;

- можливість надсилати запити на товари безпосередньо 3 примірочної до портативного пристрою продавців (Personal Digital Assistant).

2. «нтертоп+» персональний цифровий асистент:

- інструмент продажу, призначений для продавців-консультантів у магазині;

- може бути використаний для перегляду магазинів та повного каталогу товарів, тобто допомагати у питаннях, що стосуються товарних запасів або деталей товару;

- практичне застосування відбуватиметься через додаток на телефоні.

3. «Інтертоп +» інфрормаційний пост - сенсорний екран й RFID-зчитувач та конорігурація антени, що і в примірочній, 3 тими ж функціями, але розміщений у загальній зоні магазинів; клієнт може скористатись ним як самостійно, так і звернутись за допомогою до консультанта.

4. «Інтертоп+» полиця - інструмент для збору даних про поведінку споживачів та попередження торгового персоналу, коли запас полиці закінчиться.

5. «Інтертоп +» POS або точка продажу це рішення для касира з підтримкою RFID та моніторинг поточної ситуації на рівні запасів.

6. «Інтертоп+» медіа станція: оснащена додатковим 40-дюймовим РК-екраном, щоб привернути увагу клієнтів та забезпечити їм візуальний маркетинг, пропозиції товарів та медіа-ролик для фротографій і відео.

7. «Інтертоп+» протиугінна система використовує вже прикріплені RFID-мітки як пристрої сигналізації; протиугінні ворота оснащені антенами, що контролюють переміщення предметів між ними; завдяки характеристикам антени вони можуть бути інтегровані в практично будь-яку конструкцію воріт або заховані в стінах.

Для того, щоб оцінити наскільки ефрективно компанія ТОВ «Інтертоп Україна» обрала виробника модульних систем «Інтертоп+», а саме - RDN, скористаємося методом багатокритеріального аналізу. Для цього спочатку потрібно буде виділити наступні критерії оці- 
нювання компаній з виробництва мікросхем RFID з ідентичним функціоналом:

1) Кількість реалізованих проектів. Цей показник відображає рівень репутації компанії, досвідченість його працівників та успішність.

2) Кількість впроваджених мікросхем саме в галузі рітейлу. Оскільки ТОВ «Інтертоп Україна» працює у сорері роздрібної торгівлі, то кращим буде залучити компанію, яке має успішний досвід реалізації проектів у даній сорері.

3) Ширина портороліо послуг та функціоналу виробника 3 виробництва мікросхем. Цей показник буде вимірюватися шляхом експертного оцінювання у балах. Компанія, що матиме максимальний перелік функціоналу мікросхем, отримає 4 балів, а та компанія, що матиме мінімальну кількість фрункцій - 1 бал.

4) Вартість послуг.

5) Кількість перемог у профресійних проектах та місце у світовому рейтингу компаній 3 виробництва та впровадження мікросхем.

В якості альтернатив були відібрані чотири компанії, які займаються виробництвом та впровадження мікросхем RFID:

1) Альтернатива 1: Hewlett Packard. Кількість проектів - 500. Кількість впроваджених мікросхем саме в галузі рітейлу - 27. Ширина портороліо послуг та фрункціоналу виробника 3 виробництва мікросхем: охоронна фрункція та фрункція відеонагляду. Вартість послуг 480 000. Має 16 профресійних нагород [8].

2) Альтернатива 2: Intel. Кількість проектів 1500. Кількість впроваджених мікросхем саме в галузі рітейлу - 160. Ширина портфоліо послуг та фрункціоналу виробника з виробництва мікросхем: охоронна фрункція та фрункція відеонагляду, фрункція підсортування, роботи з залишками товару, штучний інтелект. Вартість послуг 450 000. Має 21 професійну нагороду [9].

3) Альтернатива 3: RDN. Кількість проектів - 2 649. Кількість впроваджених мікросхем саме в галузі рітейлу - 327. Ширина портфоліо послуг та фуункціоналу виробника з виробництва мікросхем: охоронна фрункція, фрункція підсортування, роботи з залишками товару, штучний інтелект. Вартість послуг 500000. Має 15 професійну нагороду [10].

4) Альтернатива 4: Arm. Кількість проектів - 1000. Кількість впроваджених мікросхем саме в галузі рітейлу - 13. Ширина портфроліо послуг та фрункціоналу виробника з виробництва мікросхем: охоронна фрункція, фрункція підсортування, роботи з залишками товару. Вартість послуг 280 000. Немає нагород [11].

Таким чином, у результаті постановки задачі багатокритеріального вибору отримали матрицю рішень (табл. 1).

Для проведення оцінювання спочатку встановлюємо вагові коефріцієнти критеріїв оцінювання за методом SMART [1]. 100 балів присвоюємо найважливішому критерію. Далі визначаємо відносні вагові оцінки критеріїв за фрормулою:

$$
W_{i}=\frac{W_{i}}{\sum_{i=1}^{5}{ }^{*} W_{i}}
$$

де $W_{i}$ ваговий коефріцієнт встановлений за методом SMART. Отримані дані відобразимо у таблиці 2.

За допомогою методики TOPSIS (Technique for order preference be similarity to ideal solution) проведемо оцінювання альтернатив [1]. Спочатку знаходимо значення нормалізованої матриці рішень за фрормулою:

$$
u_{i j}=\frac{x_{i j}}{\sqrt{\sum x_{k j}^{2}}},
$$

де $x_{i j}-$ значення $i$-ої альтернативи за $j$-им критерієм;

$\sum x_{k j}^{2}$ - сума квадратних значень всіх альтернатив за ј-им критерієм.

За цією формулою розрахуємо значення нормалізованої матриці рішень для вибору компанії з виробництва мікросхем для «Інтертоп+» (табл. 3).

Далі зважуємо нормалізовану матрицю рішень множенням кожного елемента на ваговий коефріцієнт (табл. 4).

Таблиця 1

\begin{tabular}{|c|c|c|c|c|c|}
\hline Альтернатива & $\begin{array}{c}\text { Кількість } \\
\text { реалізованих } \\
\text { проектів }\end{array}$ & $\begin{array}{c}\text { Кількість } \\
\text { впроваджених } \\
\text { мікросхем в } \\
\text { галузі рітейлу }\end{array}$ & $\begin{array}{c}\text { Ширина } \\
\text { портороліо } \\
\text { послуг }\end{array}$ & $\begin{array}{l}\text { Вар-ть } \\
\text { послуг, \$ }\end{array}$ & \begin{tabular}{|c|} 
Кількість \\
перемог у \\
профресійних \\
проектах
\end{tabular} \\
\hline Hewlett-Packard & 500 & 27 & 1 & 480000 & 16 \\
\hline Intel & 1500 & 160 & 4 & 450000 & 21 \\
\hline RDN & 2649 & 327 & 3 & 500000 & 15 \\
\hline Arm & 1000 & 13 & 2 & 280000 & 0 \\
\hline
\end{tabular}

Матриця багатокритеріального аналізу для порівняння альтернатив

Джерело: узагальнено авторами на основі [8; 9; 10; 11] 
Визначення вагових коефіцієнтів за методом SMART

\begin{tabular}{|l|c|c|c|c|c|}
\hline Альтернатива & $\begin{array}{c}\text { Кількість } \\
\text { реалізованих } \\
\text { проектів }\end{array}$ & $\begin{array}{c}\text { Кількість } \\
\text { впроваджених } \\
\text { мікросхем в } \\
\text { галузі рітейлу }\end{array}$ & $\begin{array}{c}\text { Ширина } \\
\text { портороліо } \\
\text { послуг }\end{array}$ & $\begin{array}{c}\text { Кількість } \\
\text { веремог у } \\
\text { послуг, \$ } \\
\text { професійних } \\
\text { проектах }\end{array}$ \\
\hline Hewlett-Packard & 500 & 27 & 1 & 480000 & 16 \\
\hline Intel & 1500 & 160 & 4 & 450000 & 21 \\
\hline RDN & 2649 & 327 & 3 & 500000 & 15 \\
\hline Arm & 1000 & 13 & 2 & 280000 & 0 \\
\hline $\begin{array}{l}\text { Baгові } \\
\text { коедріцієнти Wi }\end{array}$ & 60 & 70 & 100 & 80 & 40 \\
\hline wi & 0,17 & 0,2 & 0,29 & 0,23 & 0,11 \\
\hline
\end{tabular}

Джерело: узагальнено авторами

Таблиця 3

Нормалізована матриця рішень для вибору компанії

з виробництва мікросхем для «Інтертоп+»

\begin{tabular}{|l|c|c|c|c|c|}
\hline Альтернатива & $\begin{array}{c}\text { Кількість } \\
\text { реалізованих } \\
\text { проектів }\end{array}$ & $\begin{array}{c}\text { Кількість } \\
\text { вроваджених } \\
\text { мікросхем в } \\
\text { галузі рітейлу }\end{array}$ & $\begin{array}{c}\text { ширина } \\
\text { портфоліо } \\
\text { послуг }\end{array}$ & $\begin{array}{c}\text { Кількість } \\
\text { послуг \$ } \\
\text { перемог у } \\
\text { професійних } \\
\text { проектах }\end{array}$ \\
\hline Hewlett-Packard & 0,1541771 & 0,0739165 & 0,1825577 & 0,550 & 0,526931 \\
\hline Intel & 0,4625313 & 0,4380242 & 0,7302308 & 0,515 & 0,691598 \\
\hline RDN & 0,8168303 & 0,8952120 & 0,5476731 & 0,573 & 0,493998 \\
\hline Arm & 0,3083542 & 0,0355894 & 0,3651154 & 0,320 & 0 \\
\hline$\sqrt{\sum x_{k j}^{2}}$ & 3243,0234 & 365,2766 & 5,47772 & 872525 & 30,36445 \\
\hline
\end{tabular}

Джерело: узагальнено авторами

Таблиця 4

Зважена нормалізована матриця рішень для вибору компанії з виробництва мікросхем для «Інтертоп+»

\begin{tabular}{|l|c|c|c|c|c|}
\hline Альтернатива & $\begin{array}{c}\text { Кількість } \\
\text { реалізованих } \\
\text { проектів }\end{array}$ & $\begin{array}{c}\text { Кількість } \\
\text { вповаджених } \\
\text { мікросхем в } \\
\text { галузі рітейлу }\end{array}$ & $\begin{array}{c}\text { Ширина } \\
\text { портфоліо } \\
\text { послуг }\end{array}$ & $\begin{array}{c}\text { Вартість } \\
\text { послуг, \$ }\end{array}$ & $\begin{array}{c}\text { Кількість } \\
\text { перемог у } \\
\text { просійних } \\
\text { проектах }\end{array}$ \\
\hline Hewlett-Packard & 0,02621 & 0,01478 & 0,05294 & 0,12650 & 0,05796 \\
\hline Intel & 0,07353 & 0,08760 & 0,21176 & 0,11845 & 0,07607 \\
\hline RDN & 0,13886 & 0,17904 & 0,15882 & 0,13179 & 0,05433 \\
\hline Arm & 0,05245 & 0,00711 & 0,10588 & 0,07360 & 0 \\
\hline wi & 0,17 & 0,2 & 0,29 & 0,23 & 0,11 \\
\hline
\end{tabular}

Джерело: узагальнено авторами

У зваженій нормалізованій матриці визначаємо «ідеальну» позитивну і негативну альтернативи за кожним критерієм (вони позначені кольором в матриці: зелений колір - «ідеальна» позитивна альтернатива, жовтий - «ідеальна» негативна альтернатива).

Далі обчислюємо відстані від кожної альтернативи до «ідеальної» $S_{i}^{+}$позитивної та «ідеальної» $S_{i}^{-}$негативної альтернатив та їх рейтинг $R_{i}$ за срормулами [92]:

$$
\begin{gathered}
S_{i}^{+}=\sqrt{\sum_{j=1}^{m}\left(u_{i j}-u_{j}^{+}\right)} 2 \\
S_{i}^{-}=\sqrt{\sum_{j=1}^{m}\left(u_{i j}-u_{j}^{-}\right)} 2 \\
R_{i}=\frac{S_{i}^{-}}{S_{i}^{-}+S_{i}^{+}}
\end{gathered}
$$

У таблиці 5 подано відстані від кожної альтернативи до «ідеальної» позитивної до «іде- 
Матриця відстаней від альтернатив до «ідеально» позитивної

Таблиця 5 та «ідеально» негативної альтернатив, їх рейтинг

\begin{tabular}{|l|l|l|l|}
\hline \multicolumn{1}{|c|}{ Альтернатива } & \multicolumn{1}{|c|}{$\boldsymbol{S}_{i}^{+}$} & \multicolumn{1}{c|}{$\boldsymbol{S}_{i}^{-}$} & \multicolumn{1}{c|}{$\boldsymbol{R}_{\boldsymbol{i}}$} \\
\hline Hewlett-Packard & 0,62475 & 0,68401 & 0,52263 \\
\hline Intel & 0,98304 & 1,22798 & 0,45227 \\
\hline RDN & 1,20611 & 1,46698 & 0,54879 \\
\hline Arm & 0,48845 & 0,33768 & 0,40874 \\
\hline
\end{tabular}

Джерело: узагальнено авторами

альної» негативної альтернатив та їх рейтинг (близькість до ідеального рішення).

Лінійне упорядкування альтернатив за їх рейтингом (у порядку спадання рейтингової оцінки) зобразимо в таблиці 6.

Таблиця 6

Лінійне упорядкування агентств компанії з виробництва мікросхем за їх рейтингом

\begin{tabular}{|l|c|}
\hline Альтернатива & Рейтинг альтернативи \\
\hline RDN & 0,54879 \\
\hline Hewlett-Packard & 0,52263 \\
\hline Intel & 0,45227 \\
\hline Arm & 0,40874 \\
\hline
\end{tabular}

Джерело: узагальнено авторами

Отже, найкращою альтернативою за методом TOPSIS $€$ виробник RDN із рейтинговим значенням 0,54879.

Висновки. На сучасному етапі підприємство виступає одним з активних учасників інноваційної екосистеми. Воно одночасно $€$ як споживачем інновацій, так й їх генератором. Прискорення процесів цисрровізації діяльності суб'єктів господарювання на даний момент спричинене COVID-19. Проте це було тільки поштовхом до активізації впровадження сучасних технологій в активне використання. Однією зі чутливих до даних процесів сорер є рітейл. Проведене дослідження вказує на значні здобутки у цьому напрямі одного із сильних гравців вітчизняного ринку ТОВ «Інтертоп Україна». Компанією вже впроваджені нові технології ERP-систем, що дає переваги в управлінні та активно впроваджуються сервісні технології співпраці 3 клієнтами. Для подальшого розвитку і збереження конкурентоздатності компанії доцільним $€$ продовження вдосконалення взаємовідносин з клієнтом, а саме поєднання он-лайн та офрфр-лайн обслуговування, та подальшого впровадження нових технологій управління бізнес-процесами.

\section{СПИСОК ВИКОРИСТАНИХ ДЖЕРЕЛ:}

1. Балан В. Г. Стратегічне управління. Методи портфельного аналізу : Навчальний посібник. Київ : Наукова столиця, 2018. 188 с.

2. Лановська Г. І. Інноваційна екосистема : сутність та принципи. Економіка і суспільство. 2017. № 11. C. $257-262$.

3. Петренко Л. А., Проскокова А. Ю. Тенденції розвитку та впровадження інновацій підприємствами ссрери рітейлу. Стратегія економічного розвитку України. 2020. № 46. С. 86-100.

4. Федулова Л. І., Марченко О. С. Інноваційні екосистеми : сутність та методологічні засади формування. Економічна теорія і право. 2015. № 2(21). С. 21-33.

5. Typical Actors in an Innovation Ecosystem. URL: https://www.idiainnovation.org/ecosystem-actors

6. Global retail trends 2020. Preparing for the new reality. URL: https://home.kpmg/ua/uk/home/insights/2020/05/ global-retail-trends-2020-preparing-for-new-reality.html

7. SAP S/4HANA для INTERTOP: лідер fashion рітейл впровадив ERP разом 3 AGELESS. URL: https://ageless.com.ua/news/sap-s-4hana-dlya-intertop-lider-fashion-rytejl-vprovadyv-erp-razom-z-ageless/

8. Hewlett Packard Enterprise: Around HPE. URL: https://www.hpe.com/us/en/home.html

9. Intel Shapes the Future of Technology. URL: https://www.intel.com/content/www/us/en/company-overview/ company-overview.html

10. About RDN. URL: https://www.recoverydatabase.net/

11. A Global Ecosystem of Innovators. URL: https://www.arm.com/company

12.Умови та переваги Програми INTERTOP PLUS. URL: https://intertop.ua/ua/intertop-plus/ 


\section{REFERENCES:}

1. Balan V. G. (2018) Strategichne upravlinnya. Metody portfelnogo analizu [Strategic management. Methods of portfolio analysis]: Navchalnyy posibnyk [Textbook]. Kyiv: Naukova stolytsya, 188 p. (in Ukrainian)

2. Lanovska G. I. (2017) Innovatsiyna ekosystema: sutnist ta pryntsypy [Innovative ecosystem: essence and principles]. Ekonomika i suspilstvo, no. 11, pp. 257-262.

3. Petrenko L. A., Proskokova A. U. (2020) Tendentsiyi rozvytku ta vprovadzhennya innovatsiy pidpryemstvamy sfery riteylu [Trends in the development and implementation of innovations by retail enterprises]. Strategiya ekonomichnogo rozvytku Ukrayiny, no. 46, pp. 86-100.

4. Fedulova L. I., Marchenko O. S. (2015) Innovatsiyni ekosystemy: sutnist ta metodologichni zasady formuvannya [Innovative ecosystems: essence and methodological principles of formation]. Ekonomichna teoriya i parvo, no. 2(21), pp. 21-33.

5. Typical Actors in an Innovation Ecosystem. URL: https://www.idiainnovation.org/ecosystem-actors

6. Global retail trends 2020. Preparing for the new reality. URL: https://home.kpmg/ua/uk/home/insights/2020/05/ global-retail-trends-2020-preparing-for-new-reality.html

7. SAP S/4HANA dlya INTERTOP: lider fashion riteyl vprovadyv ERP razom z AGELESS [SAP S/4HANA for INTERTOP: fashion retail leader has introduced ERP with AGELESS]. URL: https://ageless.com.ua/news/sap-s4hana-dlya-intertop-lider-fashion-rytejl-vprovadyv-erp-razom-z-ageless/

8. Hewlett Packard Enterprise: Around HPE. URL: https://www.hpe.com/ru/ru/home.html

9. Intel Shapes the Future of Technology. URL: https://www.intel.com/content/www/us/en/company-overview/ company-overview.html

10. About RDN. URL: https://www.recoverydatabase.net/

11. A Global Ecosystem of Innovators. URL: https://www.arm.com/company

12. Umovy ta perevagy Programy INTERTOP PLUS [Terms and benefits of the INTERTOP PLUS Program]. URL: https://intertop.ua 